\title{
Recenzja książki Ryszard F. Sadowski, 2015, Filozoficzny spór o rolę chrześcijaństwa w kwestii ekologicznej, Towarzystwo Naukowe Franciszka Salezego, Warszawa
}

\author{
Marcin Pełka \\ Instytut Filozofii, Wydział Humanistyczny \\ Uniwersytet Mikołaja Kopernika w Toruniu \\ ul. Fosa Staromiejska 1a, 87-100 Toruń \\ smut_ny@poczta.fm
}

W roku $2015 \mathrm{w}$ ręce czytelników trafiła monografia pt. Filozoficzny spór o role chrześcijaństwa w kwestii ekologicznej autorstwa księdza profesora Ryszarda F. Sadowskiego, wykładowcy UKSW w Warszawie. Na płaszczyźnie filozofii ekologicznej stanowi ona bardzo ważną pozycję. Ukazuje bowiem kwestię domniemanej odpowiedzialności religii chrześcijańskiej za współczesny kryzys ekologiczny. Jak zauważa sam autor (s. 11), już od pół wieku trwa spór o to, czy chrześcijaństwo jest współodpowiedzialne za stworzenie dominującego dziś w naszej cywilizacji paradygmatu - niczym nieograniczonego wzrostu gospodarczego - który przekłada się na wciąż postępujące wyniszczanie naturalnego dobrostanu naszej planety. W roku 1967 w czasopiśmie „Science” Lynn Townsend White Junior opublikował artykuł The Historical Roots of Our Ecologic Crisis, stanowiący treść wygłoszonego kilka miesięcy wcześniej wystąpienia konferencyjnego. Postawiona w nim teza, że judeochrześcijańskie podejście do środowiska usprawiedliwia (...) charakterystyczna dla cywilizacji Zachodu "eksploatacyjna” relację do przyrody (s. 102), wywołała sporo kontrowersji i zapoczątkowała trwające po dziś dzień polemiki. Sadowski czyni tezę White'a punktem wyjścia do własnych badań, aby ukazać tło historyczne tego sporu, a później zaprezentować własne stanowisko. Trudno nie zgodzić się z autorem, że $w$ polskim środowisku naukowym nie poświęcono temu zagadnieniu zbyt wiele uwagi (s. 11). To jedynie podkreśla wartość jego pracy, stanowiącej pierwszą w naszej rodzimej literaturze monografię służącą naświetleniu i popularyzacji tej problematyki. Rozprawa księdza profesora w sposób bardzo przejrzysty prezentuje wszystkie złożone kwestie, jakie ogniskują się wokół postawionego zagadnienia. Monografia Sadowskiego stanowi ważny głos w sporze wskazanym przez jej tytuł. Przejdźmy zatem do prezentacji jej zawartości, aby lepiej uzasadnić to twierdzenie.

Rozdziat 1, noszący tytuł Intelektualne tto sporu, podzielony został na dwie części. W pierwszej z nich autor ukazuje proces dojrzewania gatunku ludzkiego do postawy odpowiedzialności za naturalne środowisko. Wskazuje, że już od starożytności trwało opozycyjne ujmowanie człowieka i przyrody, dostrzegano jednak, że to właśnie warunki 
naturalne wpływały na odmienność ludzkich kultur. Doprowadziło to do powstania „koncepcji determinizmu środowiskowego”, która wykrystalizowała się w pełni w wieku XIX. Dopiero początek XX wieku przyniósł nowe ujęcie zagadnienia, jakim jest „koncepcja posybilizmu środowiskowego", a więc przekonanie, że naturalne środowisko tworzy różne możliwości ludzkiego rozwoju, zaś to od człowieka (jeżeli jest świadomy skutków podejmowanych działań) zależy którą drogę rozwojową wybierze. Ten nowy sposób myślenia okazuje się szczególnie konieczny w czasach, gdy samoregeneracyjne możliwości przyrody przestają nadążać za wciąż przyśpieszającą eksploatacją jej zasobów. Drugi punkt rozdziału poświęcony jest ukazaniu historycznego rozwoju nauk humanistycznych zaangażowanych na rzecz ekologii oraz przypomnieniu międzynarodowych konferencji i porozumień ponadpaństwowych, które miały budzić świadomość proekologiczną i ograniczać szkodliwy wpływ człowieka na środowisko. Za przesadną skromność powinniśmy uznać przekonanie autora, że dokonuje jedynie wstępnego, ogólnego zarysu tej problematyki. Zostaje ona zaprezentowana bardzo fachowo i szeroko, a ponadto poszerzona jest o zagadnienia filozofii zrównoważonego rozwoju i przegląd stanowisk polskich badaczy reprezentujących filozoficzne stanowiska proekologiczne. Bardzo ważnym okazuje się też stwierdzenie, że zarówno chrześcijańskie, jak i niechrześcijańskie tradycje religijne mają duży wkład w szerzenie postawy proekologicznej. Religie posiadają bowiem zdolność docierania do szerokich mas społecznych oraz potencjat intelektualno-duchowy (s. 54), który pod postacią ekoteologii sprzyja próbom przezwyciężenia globalnego kryzysu ekologicznego.

Rozdziat 2, noszacy tytuł Geneza sporu, zestawia dwa obrazy świata: nowożytny i chrześcijański. Na pierwszy rzut oka wydaje się, że jest to odwrócenie historycznego porządku, jednak taka kolejność ma głębszy sens i podyktowana jest dobrze przemyślaną logiką wywodu. Jak zauważa ksiądz profesor, nowożytny obraz świata stopniowo wykształcał się w naszej cywilizacji już od czasów społeczeństw pierwotnych. W pierwszej fazie rozwoju nie było jeszcze przeciwstawiania nieświadomej przyrody i świadomego człowieka (s. 61). Pojawia się ono dopiero wraz z rolnictwem i pasterstwem, gdy ludzie zaczynają przekształcać przyrodę do własnych celów. W czasach starożytnej Grecji filozofowie dokonali przeciwstawienia człowiek - przyroda, w efekcie czego pojawiła się tendencja do wyróżniania istoty ludzkiej i uprzedmiotowiania natury. Wieki średnie stanowią czas przenikania się antycznego i chrześcijańskiego obrazu świata, za oczywiste uchodzi przekonanie, że Bóg stworzył świat przyrody i człowieka, w każdym z nich pozostawiając ślady swego istnienia. Nowożytność jest czasem stopniowego odchodzenia od średniowiecznej wizji człowieka jako członka wspólnoty religijnej i człowieka jako integralnej części świata stworzonego przez Boga. Autor dokonuje bogatego przeglądu kolejnych stanowisk filozoficzno-naukowych, który da się streścić jako prezentację krystalizowania się wizji człowieka jako istotny zdolnej badać, poznawać, odkrywać i finalnie podporządkowywać własnym celom świat naturalny. W drugiej części rozdziału ksiądz profesor wykazuje, że (wbrew krytykom) obowiązującego od nowożytności paradygmatu nie da się uzasadnić treścią Pisma Świętego. W tym celu dokonuje analizy dwóch opisów stworzenia świata, jakie spotykamy w Księdze Rodzaju. Pierwszy z nich jasno ukazuje, że człowiekowi została powierzona misja doglądania i opieki nad całością stworzenia (na zasadzie dobrego pasterza), a nie podporządkowania go własnym celom (na zasadzie uprzywilejowanego tyrana). Drugi, znaczeni krótszy opis, uzupełniony jest wizją Edenu, a więc pierwotnego, harmonijnego współżycia człowieka z Bogiem i przyrodą. Człowiek nie jest tu przedstawiany jako pan rajskiego ogrodu, lecz raczej jako jego sługa, który musi go stale strzec i doglądać. Rozdział ten kończy się punktem ukazującym jak w myśli filozofów wczesnochrześcijańskich przenikał 
się antyczny i biblijny obraz świata. Dokonanie powyższych analiz służy uargumentowaniu postawionej wcześniej tezy: wszystko wskazuje na to, że współczesny kryzys ekologiczny jest konsekwencja wypierania chrześcijańskiego obrazu świata przez nowożytny obraz świata oraz konsekwencje stąd wynikajace (s. 83).

Rozdziat 3 zawiera kolejne zestawienie. Tym razem Sadowski ukazuje poglądy zwolenników i przeciwników tezy postawionej przez White'a. Jest to przegląd subiektywnie dobranych stanowisk, nie ulega jednak wątpliwości, że autor przywołuje różne, reprezentatywne przypadki, podkreślając nawet w pewnym miejscu, iż niekiedy trudno jest jednoznacznie zakwalifikować niektórych uczestników debaty (s. 125, przyp. 397). Przegląd rozpoczyna od wynotowania głównych tez niespełna pięciostronicowego tekstu samego White'a, który jest główną przyczyną sporu polaryzującego stanowiska różnych badaczy. White postawił tezę, że ani w czasach przedchrześcijańskich, ani w innych kulturach, nie mamy do czynienia z paradygmatem niczym nieograniczonej eksploatacji naturalnego środowiska. Jak stwierdza, tradycja judeochrześcijańska tylko człowieka postrzega jako istotę uduchowioną, odmawiając jakiejkolwiek duchowej wartości naturze, która została zdegradowana poprzez nadanie człowiekowi wyróżnionego i uprzywilejowanego miejsca w świecie. Podobnego zdania była Arnold Joseph Toynbee. Uważał on, że odpowiedzialne za współczesny kryzys ekologiczny są zachodnie religie monoteistyczne (judaizm, chrześcijaństwo, mahometanizm), gloryfikujące rolę człowieka i pobudzające ludzką chciwość. Co znamienne, propagowania takiej postawy nie ma w religiach politeistycznych, które zawsze ukazują harmonijne współżycie ludzi i natury. Do odrzucenia judeochrześcijańskiej tradycji wzywał także Max Nicolson, odnajdując w Starym Testamencie mity przyzwalające na rabunkową politykę względem naturalnych zasobów naszej planety. Zdaniem Iana Lennoxa McHarga antropocentryzm promowany przez judaizm, chrześcijaństwo i humanizm nadawał człowiekowi absolutną władzę nad przyrodą, czego nie można powiedzieć o wcześniejszych religiach, które podporządkowywały człowieka prawom przyrody i nakazywały mu uległość względem niej. Podobne, acz nieco mniej krytyczne stanowiska zajęli także Donald Worster i John Passmore.

Po drugiej stronie sporu znajdują się stanowiska autorów, którzy nie podzielają lub osłabiają zarzuty White'a. Robin Attfiled udowadnia, że w Starym i Nowym Testamencie jest wiele dobitnych przykładów ukazujących, że Bóg nakazuje człowiekowi troszczyć się o świat natury oraz że za pomocą treści Biblii nie da się uzasadnić ani ujęcia antropologicznego, ani despotycznej relacji ludzi względem przyrody. Zdaniem Johna Bairda Callicotta twierdzenia White'a są zbyt powierzchowne. Nie można bowiem twierdzić, że to religia jest jedynym lub głównym sprawcą działań, jakie podejmuje dana kultura, zaś dualizm świata i człowieka wynika w naszej kulturze nie z chrześcijaństwa, lecz z filozofii greckiej, a lektura Księgi Rodzaju jasno wskazuje, że Bóg w równej mierze troszczy się o każdą stworzoną przez siebie istotę. Również James A. Nash uważał, że religia nie jest jedynym czynnikiem kulturotwórczym, jednak w kwestii odpowiedzialności chrześcijaństwa za współczesny kryzys ekologiczny zajął stanowisko nieco bardziej umiarkowane. W jego mniemaniu chrześcijaństwo zrobiło zbyt mato, by zniecheccić i zbyt wiele, by zachęcić do nadużywania przyrody (s. 136). Antropocentryzm zawarty w tej religii, jak i fakt, że zawsze za mało uwagi poświęcała zagadnieniom ochrony świata przyrody, są dla tego badacza równie oczywiste, jak fakt, że współcześnie chrześcijaństwo odgrywa wielką rolę w kształtowaniu postawy odpowiedzialności za naturalny dobrostan naszej planety. Krytycznie o twierdzeniach White'a wypowiedziała się też Elspeth Whitney, która uważa jego wystąpienie za zbyt jednostronne, momentami nie merytoryczne, a przy tym prowokacyjne i przyjęte przez wiele środowisk naukowych bez głębszej 
analizy. Z podobnego przekonania wychodzą także Sir Keith Vivian Thomas, Lewis Whitfield Moncrief i Yi-Fu Tuan. Zbieżne w ich stanowiskach okazują się zwłaszcza zarzuty przeszacowania przez White'a kulturotwórczej mocy myśli judeochrześcijańskiej (traktowanie chrześcijaństwa jako jedynego czynnika tworzącego naszą cywilizację) i ujmowanie innych czy wcześniejszych kultur jako wolnych od paradygmatu nieograniczonej eksploracji naturalnych zasobów.

Rozdziat 4 nosi nazwę Ptaszczyzny sporu i służy ukazaniu złożoności polemik, jakie toczą się pomiędzy wspomnianymi już reprezentantami omawianego dyskursu. Sadowski bardzo przejrzyście ukazuje wieloaspektowość i wielowątkowość poruszanych zagadnień, rozpatrując je na czterech płaszczyznach: ontologicznej, antropologicznej, epistemologicznej i semantycznej. Nie jest naszym zamiarem dokładne streszczanie tego rozdziału, zwłaszcza że objętościowo zajmuje on niemal trzecią część całej pracy i porusza bardzo wiele kwestii, wynotujmy za to kilka spośród najważniejszych wniosków, jakie przedstawia nam ksiądz profesor. Z perspektywy ontologicznej wielu zwolenników tezy White'a wzywa do zerwania z chrześcijańską religią i jej tradycją, lub podnosi postulat ich przemodelowania, aby ograniczyć zgubny wpływ na środowisko. Jak się jednak okazuje, zwrot w stronę pierwotnych wierzeń animistycznych nie jest żadnym remedium na problemy ekologiczne - mit „szlachetnego dzikiego”, żyjącego w symbiozie z uduchowioną przyrodą, jest typową ekologiczną legendą (s. 167), gdyż niezależne badania potwierdzają, że idealizowani w amerykańskich rozprawach Indianie częstokroć dopuszczali się wyniszczania lokalnych ekosystemów w stopniu nie mniejszym, niż współcześni im Europejczycy. Analizując statystyki dotyczące poszczególnych epok historycznych możemy zaś dostrzec, że szkodliwy paradygmat niczym nieograniczonej eksploatacji natury zawsze był obecny we wszystkich kulturach, nawet tak odległych, jak dalekowschodnie. Widać więc jasno, że był to zawsze problem nie tylko naszej cywilizacji, współtworzonej przez religię chrześcijańską. Zresztą religia ta nie stworzyła podejścia antropocentrycznego, lecz jedynie podtrzymała antropocentryczne rozumienie świata zaprezentowane przez Greków. Próba zarzucenia antropocentryzmu (jeśli w ogóle jest możliwa) jeszcze nigdy nie zakończyła się sukcesem. Nie jest ona jednak konieczna, gdyż wbrew zwolennikom White'a, antropocentryzm nie jest synonimem egoizmu, a więc nie musi oznaczać egoistycznego podejścia człowieka do dóbr natury (s. 199). Na płaszczyźnie antropologicznej uczestnicy sporu zasadniczo zgadzają się odnośnie złej kondycji człowieka, która pozostaje sprzężona ze stopniem zdewastowania naturalnego środowiska, przedmiotem sporu pozostaje na ile zachłanność leży w naturze człowieka i w jakim stopniu chrześcijaństwo przyzwala na jej zaspokajanie. Złożone spory przebiegają także na płaszczyźnie epistemologicznej. Uczestnicy, posiadający filozoficzne wykształcenie w różnym, często znikomym stopniu, wytykają sobie nierzetelność, nieprawdziwość informacji, a nawet manipulowanie faktami, aby służyły ich własnym celom, często nie związanym z właściwym przedmiotem dyskursu. Jest to szczególnie istotne z perspektywy kolejnych zagadnień: z określeniem na ile chrześcijaństwo, nie będące przecież jedynym fundamentem naszej cywilizacji, jest odpowiedzialne za kryzys ekologiczny (czy może nawet odgrywa pod tym względem rolę pozytywną, a więc skrajnie przeciwną wnioskom White'a); z określeniem roli, jaką odegrało chrześcijaństwo w rozwoju nauki i technologii; a także z kwestią złożoności współczesnego kryzysu ekologicznego. Bardzo przejrzystą okazuje się za to perspektywa semantyczna. Łatwo udowodnić, że White i jego stronnicy dokonali nadinterpretacji wybiórczo czytanych fragmentów Księgi Rodzaju, zaś historia interpretacji Pisma Świętego aż do XVII wieku (a więc do czasu powstania nowożytnego obrazu świata) dalece rozmijała się z postawą przyzwalającą na nieograniczoną eksplorację natury. 
Rozdziat 5, noszący nazwę Próby przezwyciężenia sporu, ukazuje pozytywną rolę chrześcijaństwa w działaniach na rzecz ekologii, czyniąc to z perspektywy filozofii moralnej i filozofii społecznej. Na pierwszej płaszczyźnie autor dokonuje bardzo przejrzystej prezentacji idei zrównoważonego rozwoju. Nie bez słuszności odnotowuje, że ekoteologia zajmuje szczególne miejsce jeśli chodzi o krzewienie tej idei oraz że jest to idea posiadająca również chrześcijańskie korzenie, którymi są cnoty umiarkowania i wstrzemięźliwości. Ukazuje także kwestię moralnego wymiaru zagadnień ekologicznych. Przywołując wypowiedzi czterech ostatnich papieży opisuje pojęcia "grzechu ekologicznego”, „ekologicznego nawrócenia” czy „ekosprawiedliwości”, świadczące o tym, że Kościół uważa imperatyw dbania o przyrodę za tożsamy z bożym nakazem dbania o całość stworzenia. Prezentując rolę chrześcijaństwa na drugiej płaszczyźnie (filozofii społecznej) ksiądz profesor dokonuje bardzo szerokiego wyliczenia wystąpień papieży, wysokich hierarchów Kościoła, a także działań organizacji skupiających chrześcijan, które unaoczniają wielki wpływ religii na tworzenie i wspieranie postaw i inicjatyw proekologicznych. Opisując to zagadnienie Sadowski zwraca także uwagę na szczególnie popularną w chrześcijaństwie ideę włodarzowania (ss. 344 i nn.), a więc na taki model obecności człowiek w świecie, który realizowałby zawarty w Księdze Rodzaju ideał dobrego pasterza, którego rolą jest doglądanie dzieła bożego i opieka nad nim.

Pisanie rzetelnej recenzji wymaga także wskazania słabych stron recenzowanych prac. Rzecz jednak w tym, że Sadowski nie zostawia nam takiej możliwości. Wszelkie kwestie niejasne i mogące budzić wątpliwość zostają doprecyzowane i wyjaśnione w toku narracji, co tylko podkreśla wartość jego dzieła. Można jedynie zasugerować, że w pracy powinien znaleźć się jeszcze indeks nazwisk. Taką sugestię trudno oczywiście uznać za zarzut, wydaje się jednak, że w tak obszernej rozprawie, porządkującej mnogość stanowisk i opartej na imponującej bibliografii (34 strony, 692 pozycje) indeks bywa przydatny. Sadowski uprzedził nas w kwestii wskazania adresatów swojej pracy, a więc tych spośród czytelników, dla których będzie ona szczególnie przydatna (s. 14). Słusznie stwierdził, że może się ona okazać cenną pozycją zwłaszcza dla filozofów i antropologów środowiskowych, chrześcijańskich intelektualistów badających kryzys ekologiczny oraz dla osób działających na rzecz budzenia świadomości proekologicznej i tworzenia proekologicznych postaw. 